\title{
PHYSICAL ACTIVITY AND QUALITY OF LIFE IN WOMEN WITH BREAST CANCER - A CROSS-SECTIONAL STUDY
}

\author{
ATIVIDADE FISICA E QUALIDADEDE VIDA EM MULHERES COM CÂNCERDE MAMA- \\ UMESTUDO TRANSVERSAL
}

Original Article

ARTIGO ORIGINAL

Artículo Original

ACTIVIDAD FISICA Y CALIDAD DE VIDA EN MUJERES CON CÁNCER DE MAMA - UN ESTUDIO TRANSVERSAL

\author{
Leonessa Boing \\ (Physical Education Professional) \\ Gustavo Soares Pereira \\ (Physical Education Professional) \\ Melissa de Carvalho Souza Vieira' \\ (Physical Education Professional) \\ Taysi Seemann' \\ (Physical Education Professional) \\ Allana Alexandre Cardoso \\ (Physical Education Professional) \\ Fabiana Flores Sperandio ${ }^{1}$ \\ (Physiotherapist) \\ Adriano Ferreti Borgatto² \\ (Statistician) \\ Fatima Baptista ${ }^{3}$ \\ (Physical Education Professional) \\ Adriana Coutinho de Azevedo \\ Guimarães ${ }^{1}$ \\ (Physical Education Professional) \\ 1. Universidade do Estado de Santa \\ Catarina (UDESC), Florianópolis, \\ SC, Brazil. \\ 2. Universidade Federal de Santa \\ Catarina (UFSC), Florianópolis, \\ SC, Brazil. \\ 3. Universidade de Lisboa, \\ Lisbon, Portugal.
}

\section{Correspondence:}

Rua General Estilac Leal, 260, apto 105 bl B, Coqueiros,

Florianópolis, SC, Brazil. 88080760. leonessaboing@gmail.com

\begin{abstract}
Introduction: Breast cancer treatment can cause different side effects on the quality of life of women. Physical activity, in turn, can reduce these side effects. Objective: To investigate the physical activity and quality of life of women during and after breast cancer treatment. Methods: Sample of 174 women (57.0 \pm 9.5 years) during or after clinical treatment for breast cancer. Interview questionnaire composed of general information, physical activity (IPAQ short version) and quality of life (EORTC QLQ-C30 and BR23). For statistical analysis chi-squared test or Fisher's exact test, student's t-test for independent samples, Mann-Whitney $U$ test and multiple logistic regression analyses $(p<0.05)$. Results: Most women did not achieve the physical activity guidelines, particularly those undergoing clinical treatment. Results showed longer walking time, moderate physical activity, vigorous physical activity, moderate + vigorous physical activity, and total physical activity among the women following completion of treatment. The quality of life scores were also higher among women after clinical treatment. Logistic regression indicated that every 10-minute increment to walking time results in a 19\% decrease in the probability of worse functional capacity and a $26 \%$ decrease in the probability of worse symptoms associated with treatment side effects. Conclusion: During treatment, women with breast cancer undertake less physical activity and have worse quality of life. Walking appears to be an effective type of physical activity for these women, improving quality of life during and after breast cancer treatment. Level of evidence Il; Prognostic studies - Investigation of the effect of patient characteristics on the disease outcome.
\end{abstract}

Keywords: Breast neoplasms; Quality of life; Motor activity; Walking.

\section{RESUMO}

Introdução: O tratamento do câncer de mama pode causar diferentes efeitos colaterais na qualidade de vida das mulheres. A atividade física, por sua vez, pode diminuir esses efeitos colaterais. Objetivo: Investigar a atividade física e a qualidade de vida de mulheres durante e após o tratamento para câncer de mama. Métodos: Amostra de 174 mulheres (57,0 $\pm 9,5$ anos) durante e depois do tratamento de câncer de mama. Questionário de entrevista composto de informações gerais, atividade física (versão curta do IPAQ) e qualidade de vida (EORTC QLQ-C30 e BR23). Para a análise estatística foram usados Qui-quadrado ou Exato de Fisher, teste T de Student para amostras independentes, teste U de Mann-Whitney e análises de regressão logística múltipla $(p<0,05)$. Resultados: A maioria das mulheres não atingiu as recomendações de atividade física, com destaque para as mulheres que estavam em tratamento clínico. Os resultados mostraram mais tempo de caminhada, atividade física moderada, atividade física vigorosa, atividade física moderada + vigorosa e atividade física total em mulheres após o término do tratamento. Os escores de qualidade de vida também foram mais altos entre as mulheres após o término do tratamento. A regressão logística indicou que cada acréscimo de 10 minutos no tempo de caminhada resulta em diminuição de 19\% da probabilidade de capacidade funcional mais baixa e de $26 \%$ de desenvolver mais sintomas mais graves associados aos efeitos colaterais do tratamento. Conclusão: Durante o tratamento, as mulheres com câncer de mama praticam menos AF e têm pior qualidade de vida. A prática de caminhada parece ser um tipo efetivo de atividade física para essas mulheres, melhorando a qualidade de vida durante e depois do tratamento de câncer de mama. Nível de evidência II; Estudos prognósticos - Investigação do efeito das características do paciente sobre o desfecho da doença.

Descritores: Neoplasia da mama; Qualidade de vida; Atividade motora; Caminhada.

\section{RESUMEN}

Introducción: El tratamiento del cáncer de mama puede promover diferentes efectos secundarios en la calidad de vida de las mujeres. A su vez, la actividad física puede disminuir estos efectos colaterales. Objetivo: Investigar la actividad física y la calidad de vida de las mujeres durante y después del tratamiento contra el cáncer de mama. Métodos: Muestra de 174 mujeres (57,0 \pm 9,5 años) que se encontraban en tratamiento y post tratamiento para el cáncer de mama. Cuestionario de entrevista compuesto de información general, actividad física (versión corta IPAQ) y calidad de vida (EORTC QLQ-C30 y BR23). Para análisis estadístico Chi-cuadrado o Exacto de Fisher, Test T Student para muestras independientes, U de Mann-Whitney y análisis de regresión logística múltiple $(p<0,05)$. Resultados: La mayoría de las mujeres no alcanzaron las recomendaciones de actividad física, destacando para las mujeres que 
se encontraban en tratamiento. Los resultados mostraron más tiempo de caminata, actividad física moderada, actividad física vigorosa, actividad física moderada + intensidad vigorosa y actividad física total en mujeres post tratamiento. La calidad de vida también se mostró mejor entre las mujeres después de finalizar el tratamiento. La regresión logística apuntó que cada agregado de 10 minutos en el tiempo de caminata resulta en una disminución del 19\% en la probabilidad de una peor capacidad funcional de la calidad de vida, y en un $26 \%$ de desarrollo de una peor sintomatología en relación a los efectos colaterales del tratamiento. Conclusión: Durante el tratamiento, las mujeres con cáncer de mama practican menos actividad física y presentan peor calidad de vida. La práctica de caminar parece un tipo efectivo de actividad física para mujeres con cáncer de mama, mejorando la calidad de vida durante y después del período de tratamiento. Nivel de evidencia ll; Estudios pronósticos - Investigación del efecto de característica de un paciente sobre el desenlace de la enfermedad.

Descriptores: Neoplasias de la Mama; Calidad de Vida; Actividad Motora; Caminata.

\section{INTRODUCTION}

A large portion of the breast cancer (BC) women suffer from symptoms as pain, fatigue, anxiety, limited movements, loss of appetite as a consequence of the treatment. ${ }^{1,2}$ These symptoms can significantly affect the quality of life (QOL) of these women. ${ }^{3}$ Recently there has been an increase in the survival rates of these patients, and it is important to investigate the recovery process and the treatment effects on the QOL to make sure better years of survival life. ${ }^{1}$

Also, women undergoing clinical treatment, namely chemotherapy, radiotherapy or hormone therapy normally changes the levels of physical activity (PA). ${ }^{4}$ Chemotherapy specifically has been pointed out as promoting reduction in the level of PA when compared with other treatments. ${ }^{5}$ However, after treatment, women can return to home and work activities ${ }^{6}$, and it can also affect the PA prevalence. ${ }^{4}$

PA has been pointed as a possible alternative and an effective complementary treatment for $\mathrm{BC}, 1,3$ because it considerably improves the $\mathrm{QOL}$ of patients and it can reduce mortality rates. ${ }^{7,89}$ PA can be associated with the improvement of the immune system and the reduction of the side effects of the treatment. ${ }^{4} \mathrm{~A}$ form of PA that can be introduced in $\mathrm{BC}$ women is walking, because is an adaptable, inexpensive and accessible activity. ${ }^{10}$

Considering that incidence rates of BC have been increasing in Brazil, investigating these variables in the different stages of the treatment, both during and after it, is necessary to make it possible to understand the changes that occur throughout the Brazilian women lives, and to identify the time for inclusion of National policies of PA intervention. Other studies have been carried out in other countries, like Germany ${ }^{4}$ and France ${ }^{8}$, but in Brazil, it is an area that has been receiving more attention recently. The aim of the present study was to investigate the $\mathrm{PA}$ and $\mathrm{QOL}$ of women during and after treatment for BC.

\section{METHODS}

An exploratory descriptive cross-sectional study composed of a non-probabilistic sample of 174 women (57.0 \pm 9.5 years), diagnosed with BC, undergoing treatment or after treatment at the Oncological Research Center (CEPON) in the city of Florianopolis, Santa Catarina, Brazil.

The inclusion criteria were: 40 - 80 years old with stage 0 to III of $\mathrm{BC}$; undergoing or after treatment of chemotherapy, radiotherapy or hormone therapy. As exclusion criteria the educational level by classification as illiterate.

The total sample size of women calculation was made by software $\mathrm{G}^{*}$ Power 3.1.9.2, considering a level of significance of 5\%; test power of $80 \%$; and risk-ratio effect size (OR and RR) of 1.61, resulting in a sample of 177 total participants.

The study was approved by the Ethics Committee on Research in $\mathrm{Hu}$ man Being (CEPSH) of UDESC, Protocol No. 688.548, and by the Research
Ethics Committee of CEPON (CEP), Protocol No. 818.174. Data were collected in the period from October 2014 to July 2015, by a structured questionnaire, in individual interview format. All the patients were invited to participate in the study voluntarily, and those who agreed signed the Term of Free and Informed Consent. For selection and eligibility of the patients, was applied the general characterization questionnaire first. From the total of 281 women collected, 107 women were not eligible, 62 because presented stage IV of BC, and 45 were younger than 40 years old, resulting in 174 women included in the final sample.

The structured questionnaire contemplated the general characterization of the sample, PA and QOL. The general characteristics of the subject (age, marital status, educational and economic level, presence of diseases, surgical interventions, mammary reconstruction, lymphedema), and weight status were self-reported. Weight status was classified by Body Mass Index (BMI) according to the WHO. ${ }^{11}$ The economic level was verified by Brazilian Institute of Geography and Statistics - IBGE. ${ }^{12}$ These variables were only presented to demonstrate a general knowledge of the sample situation.

PA was evaluated by the short version of The International Physical Activity Questionnaire - IPAQ, Brazilian reproducibility was performed by Matsudo ${ }^{13}$. It investigates the level of PA, covering six items that verify the number of times during which the subject practiced at least 10 continuous minutes of walking, moderate and vigorous PA in the last week, in different domains, namely: work, domestic, leisure, recreation and sports. For the present study, the authors opted for the following classifications: Not meeting PA guidelines, when the patient did not attain 150 minutes of PA recommended by the American College of Sports Medicine - ACSM ${ }^{14}$ for patients with cancer, and above PA guidelines, when the patient attained the 150 minutes of PA per week or practice more than 150 minutes per week. Moreover, two questions were added with reference to $P A$ practiced before diagnosis of $B C$.

To investigate the QOL, the European Organization for Research and Treatment of Cancer Quality of Life Questionnaire C30 - EORTC QLQ-C30,15 validated in Brazil ${ }^{16}$ and also the specific module for BC QLQ BR-23. ${ }^{16}$ The purpose is to verify the QOL of patients with cancer over the previous four weeks, in the following scales for C30: functional; symptomatic; and global health, and for BR23: functional and symptomatic scale. The scores goes from 0 to 100, so that for the functional and global health scales, the higher the value found, the better the QOL, differently from the symptomatic scale in which the higher value represents greater presence of symptoms, determining a worse QOL.

Statistical analysis was performed through the software IBM SPSS version 20.0. The sample was stratified into two groups: undergoing treatment (chemotherapy, radiotherapy, and hormone therapy); and after treatment. To association the Chi-Square and Exact Fisher tests were 
used. For normality calculation Kolmogorov Smirnov test was used. Since normality requirements were not met for any variable non-parametric Mann-Whitney $U$ test was used.

Associations between PA and QOL were analyzed by multivariate binary logistic regression, and the criteria used to identify and to retain variables in the multivariable models was the forward stepwise method - likelihood ratio test (entry value: 0.05 and removal value: 0.10), in order to identify the most significant PA related of QOL, namely at functional, symptomatology, and global health levels. For this purpose, the participants were divided into two groups in each level: with and without low functional level, with and without high symptomatology, and with and without low global QOL. The divisions were made separately for each scale (C30, BR23). The value of the 20th percentile of each QOL scale was used as a cutoff for separating groups. PA variables entered in the model included walking, moderate, vigorous, moderate+vigorous and total PA. For the continuous variables, the assumption of linearity was checked by the logit. The condition (under treatment and after treatment) was also controlled in the analysis. The Hosmer-Lemeshow test was used to evaluate the overall goodness-of-fit. The level of statistical significance adopted in the analyses was $p<0.05$.

\section{RESULTS}

For general knowledge, showed in Table 1, most of the sample had: a partner; basic education; came from the low class (D+E), were overweight, and underwent radical mastectomy. The women who were in the period after treatment reported greater presence of other diseases, with most them had up to one more disease, other than cancer.

Regarding mammary reconstruction, most of them did not have this performed, however, when performed, the women in the period after treatment opted for late reconstruction.

The major portions of patients not meet the PA guidelines, with emphasis on women undergoing treatment, presented in Table 2. In general, most of women practiced some PA before diagnosis of BC, with regular practice of only one activity, majority walking. Women after treatment showed higher mean values in walking, moderate PA, moderate+vigorous and total time of PA.

The characterization of QOL showed significant differences in the functional scale and in performance of roles of C30, showing higher scores for women after treatment, showed in Table 3. Also, was found significant differences in symptomatic scale and in specific symptoms with lower scores for the women after treatment. When observed BR23, significant difference was showed only in symptomatic scale, with lower scores for the women after treatment in adverse effects of systemic therapy and symptoms related to the breast.

The logistic regression in Table 4 revealed that only walking was associated with likelihood of a low functional score and a high symptomatology in the respective scales of the C30, independently of women being undergoing treatment or after treatment. The accumulation of 1 minute more per day of walking decreases $1.9 \%$ the chance of women with $\mathrm{BC}$ having a poor functional capacity and $2.6 \%$ the chance of having a high symptomatology or, considering an additional block of 10 minutes walking per day, a decrease of 19\% and 26\% in the chance of poor functional capacity and high symptomatology, respectively.

\section{DISCUSSION}

The aim of the present study was to investigate the practice of PA and QOL of women during and after treatment for BC. It was observed higher levels of PA practice for women after treatment, as well as better QOL scores in the functional and symptomatic scales. By means of logistic regression analysis, it was revealed that the addition of 10 minutes to
Table 1. General Characteristics of disease in patients undergoing treatment and after treatment for breast cancer Florianópolis, CEPON, 2014/2015. ( $n=174)$.

\begin{tabular}{|c|c|c|c|c|}
\hline Variables & $\begin{array}{l}\text { Total \% } \\
\text { (IC95\%) }\end{array}$ & \begin{tabular}{|c|} 
Undergoing \\
treatment \\
$(\%)$
\end{tabular} & $\begin{array}{c}\text { After } \\
\text { treatment } \\
(\%)\end{array}$ & $p$-value \\
\hline Marital Status & & & & $0.284^{*}$ \\
\hline Without partner & $44.3(35-51)$ & 46.6 & 37.2 & \\
\hline With partner & $55.7(48-64)$ & 53.4 & 62.8 & \\
\hline Educational level & & & & $0.389^{*}$ \\
\hline Basic schooling. & $53.4(45-60)$ & 54.2 & 51.2 & \\
\hline Medium schooling. & $33.9(27-42)$ & 35.1 & 30.2 & \\
\hline Higher education. & $12.6(7-18)$ & 10.7 & 18.6 & \\
\hline Economic Level & & & & $0.156^{* *}$ \\
\hline High Class (A+B) & $4.0(0.1 ; 0.6)$ & 2.3 & 9.3 & \\
\hline Middle Class (C) & $13.8(8-19)$ & 14.5 & 11.6 & \\
\hline Low Class (D+E) & $82.2(75-87)$ & 83.2 & 79.1 & \\
\hline Weight Status & & & & $0.216^{*}$ \\
\hline Normal weight & $27.6(20-34)$ & 30.0 & 20.0 & \\
\hline Overweight & $72.4(67-81)$ & 70.0 & 80.0 & \\
\hline Presence of other diseases & & & & $0.008^{*}$ \\
\hline Yes & $50.0(42-57)$ & 44.3 & 67.4 & \\
\hline No & $50.0(42-57)$ & 55.7 & 32.6 & \\
\hline How many diseases & & & & $0.014^{*}$ \\
\hline None & $50.0(42-57)$ & 55.7 & 32.6 & \\
\hline Up to one disease & $33.9(27-41)$ & 28.2 & 51.2 & \\
\hline Two or more diseases & $16.1(11-22)$ & 16.0 & 16.3 & \\
\hline Surgery & & & & $0.157^{* *}$ \\
\hline Radical Mastectomy & $56.3(49-64)$ & 53.4 & 65.1 & \\
\hline Conservative surgery & $38.5(31-46)$ & 39.7 & 34.9 & \\
\hline Did not undergo surgery & $5.2(2-8)$ & 6.9 & 0.0 & \\
\hline Mammary reconstruction & & & & $0.002^{*}$ \\
\hline Immediate & $17.0(11-23)$ & 18.9 & 11.6 & \\
\hline Late & $8.5(4-13)$ & 4.1 & 20.9 & \\
\hline Did not undergo procedure & $74.5(68-81)$ & 77.0 & 67.4 & \\
\hline Lymphedema & & & & $0.333^{*}$ \\
\hline Yes & $44.8(36-52)$ & 42.6 & 51.2 & \\
\hline No & $55.2(47-63)$ & 57.4 & 48.8 & \\
\hline
\end{tabular}

Table 2. Characterization of physical activity of patients undergoing treatment and after treatment for breast cancer Florianópolis, CEPON, 2014/2015. ( $n=174)$

\begin{tabular}{|c|c|c|c|c|}
\hline Variables & $\begin{array}{l}\text { Total \% } \\
(\text { IC95\%) }\end{array}$ & $\begin{array}{c}\text { Under } \\
\text { treatment } \\
(\%)\end{array}$ & $\begin{array}{c}\text { After } \\
\text { treatment } \\
(\%)\end{array}$ & p-value \\
\hline Present level of PA & & & & $0.003^{\#}$ \\
\hline Not meeting PA guidelines & $69.5(62-76)$ & 75.6 & 51.2 & \\
\hline Above PA guidelines & $30.5(23-37)$ & 24.4 & 48.8 & \\
\hline Previous regular practice of PA & & & & $0.131^{\#}$ \\
\hline Yes & $55.2(48-63)$ & 51.9 & 65.1 & \\
\hline No & $44.8(37-52)$ & 48.1 & 34.9 & \\
\hline How many activities performed & & & & $0.266^{\#}$ \\
\hline Only one activity & $66.7(62-80)$ & 63.2 & 75.0 & \\
\hline More than one activity & $33.3(19-38)$ & 36.8 & 25.0 & \\
\hline Characterization of present PA & $\bar{x}(s d)$ & $\bar{x}(s d)$ & $\bar{x}(s d)$ & \\
\hline Time of walking (min./day) & $21.0 \pm 28.0$ & $16.0 \pm 24.5$ & $36.3 \pm 32.2$ & $<0.001^{*}$ \\
\hline Time of moderate PA (min./day) & $14.3 \pm 34.0$ & $8.8 \pm 26.3$ & $30.9 \pm 46.7$ & $<0.001$ \\
\hline Time of vigorous PA (min./day) & $3.3 \pm 17.1$ & $1.4 \pm 9.0$ & $8.8 \pm 30.2$ & $0.082^{*}$ \\
\hline $\begin{array}{l}\text { Time of moderate+vigorous PA } \\
\text { (min./day) }\end{array}$ & $17.6 \pm 43.4$ & $10.3 \pm 30.9$ & $39.8 \pm 64.2$ & $<0.001^{*}$ \\
\hline Total Time of PA (min./day) & $38.6 \pm 61.0$ & $26.3 \pm 45.5$ & $76.0 \pm 83.0$ & $<0.001^{*}$ \\
\hline
\end{tabular}

Source: Constructed by the author. * Mann-Whitney U-test \# Chi-square Test. PA - Physical Activity. min./day - minutes per day. $\bar{x}$ - mean; sd - standard deviation. 
Table 3. Characterization of quality of life of patients undergoing treatment and after treatment for breast cancer Florianópolis. CEPON, 2014/2015. (n=174)

\begin{tabular}{|c|c|c|c|c|}
\hline Variables & $\begin{array}{l}\text { Total } \\
\overline{\mathbf{x}}(\mathbf{s d})\end{array}$ & $\begin{array}{c}\text { Under } \\
\text { treatment } \\
\overline{\mathbf{x}}(\mathbf{s d})\end{array}$ & $\begin{array}{c}\text { After } \\
\text { treatment } \\
\bar{x}(\mathrm{sd})\end{array}$ & p-value \\
\hline \multicolumn{5}{|l|}{ EORTC - C30 } \\
\hline Global Health Scale & $74.4 \pm 24.4$ & $74.0 \pm 25.7$ & $75.4 \pm 20.6$ & 0.873 \\
\hline Functional Scale & $68.4 \pm 21.3$ & $66.4 \pm 21.3$ & $74.5 \pm 20.4$ & 0.017 \\
\hline Cognitive function & $64.7 \pm 33.1$ & $63.3 \pm 33.9$ & $69.0 \pm 30.8$ & 0.406 \\
\hline Emotional Function & $62.4 \pm 33.1$ & $60.0 \pm 33.5$ & $69.6 \pm 31.4$ & 0.081 \\
\hline Physical Function & $70.0 \pm 35.2$ & $68.39 \pm 21.2$ & $74.4 \pm 22.7$ & 0.087 \\
\hline Social Function & $80.0 \pm 29.0$ & $77.99 \pm 30.0$ & $86.0 \pm 24.1$ & 0.132 \\
\hline Performance of roles & $69.0 \pm 35.2$ & $66.0 \pm 36.4$ & $78.7 \pm 29.6$ & 0.044 \\
\hline Symptomatic Scale & $28.3 \pm 22.1$ & $30.5 \pm 22.8$ & $21.8 \pm 18.8$ & 0.026 \\
\hline Fatigue & $37.6 \pm 33.6$ & $41.6 \pm 34.6$ & $25.6 \pm 27.2$ & 0.007 \\
\hline Loss of Appetite & $21.6 \pm 36.7$ & $25.2 \pm 38.8$ & $10.8 \pm 26.9$ & 0.019 \\
\hline Insomnia & $50.0 \pm 44.0$ & $51.6 \pm 44.8$ & $45.0 \pm 41.1$ & 0.353 \\
\hline Pain & $36.5 \pm 38.0$ & $37.4 \pm 38.8$ & $33.7 \pm 34.8$ & 0.681 \\
\hline Nausea and vomiting & $14.0 \pm 24.4$ & $16.0 \pm 26.1$ & $7.7 \pm 17.2$ & 0.050 \\
\hline Dyspnea & $11.5 \pm 27.21$ & $11.2 \pm 27.0$ & $12.4 \pm 28.2$ & 0.723 \\
\hline Constipation & $29.0 \pm 39.5$ & $28.7 \pm 39.4$ & $28.7 \pm 40.2$ & 0.921 \\
\hline Diarrhea & $7.5 \pm 23.0$ & $11.7 \pm 44.7$ & $4.6 \pm 15.6$ & 0.558 \\
\hline Financial difficulties & $32.4 \pm 40.1$ & $35.9 \pm 40.8$ & $21.7 \pm 36.3$ & 0.031 \\
\hline \multicolumn{5}{|l|}{ EORTC - BR23 } \\
\hline Functional Scale & $66.4 \pm 23.0$ & $67.7 \pm 22.6$ & $62.3 \pm 22.7$ & 0.145 \\
\hline Body image & $69.0 \pm 31.8$ & $70.1 \pm 32.0$ & $65.3 \pm 31.2$ & 0.269 \\
\hline Sexual function & $21.1 \pm 27.2$ & $18.7 \pm 25.7$ & $28.3 \pm 30.5$ & 0.065 \\
\hline Sexual satisfaction & $45.1 \pm 34.0$ & $47.8 \pm 34.2$ & $39.4 \pm 33.5$ & 0.339 \\
\hline Future perspective & $35.0 \pm 24.0$ & $33.6 \pm 40.6$ & $38.8 \pm 41.1$ & 0.377 \\
\hline Symptomatic Scale & $35.5 \pm 21.6$ & $38.0 \pm 21.0$ & $28.7 \pm 22.0$ & 0.017 \\
\hline $\begin{array}{c}\text { Adverse effects of systemic } \\
\text { therapy }\end{array}$ & $35.1 \pm 24.0$ & $37.9 \pm 24.2$ & $26.5 \pm 21.4$ & 0.005 \\
\hline Breast symptoms & $32.0 \pm 29.0$ & $34.5 \pm 28.4$ & $23.1 \pm 28.8$ & 0.008 \\
\hline Arm symptoms & $42.0 \pm 34.0$ & $41.7 \pm 32.9$ & $41.1 \pm 36.4$ & $0.797^{*}$ \\
\hline Hair loss & $50.5 \pm 45.0$ & $51.4 \pm 46.0$ & $48.1 \pm 43.1$ & 0.849 \\
\hline
\end{tabular}

Source: Constructed by the author Mann-Whitney U-test QoL - Quality of Life. Functional Scale - Greater proximity Source Construced by the author. Man-Whitey Uof the value mentioned to number 100, the worse will be the quality of life. General Scale - Greater proximity of the value mentioned to number 100 , the better will be the quality of life. $\bar{x}$ - mean; sd - standard deviation

Table 4. Logistic regression analysis between physical activity and quality of life of women with breast cancer undergoing treatment and after treatment. Florianópolis, CEPON, 2014/2015. ( $n=174)$

\begin{tabular}{|c|c|c|c|c|c|c|c|}
\hline Variables & Predictors & Coefficient & SE & $p$-value & OR & \multicolumn{2}{|c|}{ IC $95 \%$} \\
\hline & & & & & & Inferior & Superior \\
\hline $\begin{array}{c}\text { Functional Scale } \\
\text { (C30) }\end{array}$ & Walking & -0.019 & 0.009 & 0.040 & 0.981 & 0.963 & 0.999 \\
\hline $\begin{array}{l}\text { Symptomatic } \\
\text { Scale (C30) }\end{array}$ & Walking & -0.026 & 0.011 & 0.018 & 0.975 & 0.954 & 0.996 \\
\hline $\begin{array}{l}\text { Global Health } \\
\text { Scale (C30) }\end{array}$ & & 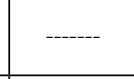 & & 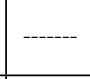 & & - & -- \\
\hline $\begin{array}{c}\text { Functional Scale } \\
\text { (BR23) }\end{array}$ & & & & -- & & - & - \\
\hline $\begin{array}{l}\text { Symptomatic } \\
\text { Scale (BR23) }\end{array}$ & & & & - & & -- & $-\cdots$ \\
\hline
\end{tabular}

Source: Constructed by the author. SE: standard error of estimate; OR: odds-ratio; IC 95\%: Interval of Confidence Scale Functional Scale Symptomatic. The condition (under treatment and after treatment) was also controlled in the analysis. the practice of daily walking implied a reduction in the probability of having low functional capacity and elevated symptomatology in 19\% and $26 \%$ of the patients, respectively.

The recommendations of PA for patients with cancer came from the American College of Sports Medicine (ACSM) ${ }^{14}$ with recommendation of regular practice of at least 150 minutes of moderate intensity per week, or 75 minutes of activities in vigorous intensity. ${ }^{14}$ The results of this study indicated that $69.5 \%$ of the sample did not achieve these recommendations; among them $75.6 \%$ were undergoing treatment, compared with $51.2 \%$ of women who had concluded it. These data corroborate those in the literature, since studies have pointed that the major portion of women with $\mathrm{BC}$ do not attain the recommendations of PA. ${ }^{7,8,9}$

The fact that most women undergoing treatment did not achieve the recommendations, suggests that treatment of $B C$ may be the factor that changes the PA of these women. ${ }^{6}$ In view of BC treatment being associated with the consequences and symptoms with lasting effects that persist for long periods, ${ }^{1}$ the PA may be made difficult and limited. Results have indicated that women undergoing treatment have pointed out more barriers and have a more negative perception of PA, with direct impact on the decrease of practice. ${ }^{17}$

Longer times of practice after conclusion of treatment may be attributed to the fact that, after treatment, women with $\mathrm{BC}$ begin the process of restructuring their daily life, returning to their routine practices, which may lead to increasing the PA. ${ }^{6}$ They also receive more encouragement from health professionals to practice. Therefore, the findings of the present study, demonstrate higher mean values of walking, moderate PA, and moderate+vigorous PA among women after conclusion of treatment when compared with those who were undergoing clinical treatment.

These values were no different when observed the QOL, demonstrating that after treatment women had higher scores in the functional scale and performance of roles. After concluding treatment, basic activities of daily life are the first to be retaken, promoting benefits to the functional capacity. ${ }^{18}$ Moreover, the lifestyle adopted by the patients regarding more practice of PA may positively influence their QOL. ${ }^{8,19}$

The symptomatic scale, both general (C30) and module for BC (BR23), demonstrated worse scores for those undergoing treatment in symptoms as fatigue, loss of appetite, nauseas and vomiting, effects of systemic therapy and breast symptoms. Considering that these symptoms are intimately associated with the consequences of treatment, which may justify the worse scores found in the present study. ${ }^{1,20}$ With special regard to fatigue, since it is one of the most common symptoms in patients with BC present in $75 \%$ to $95 \%$ of the cases. ${ }^{20,21}$

During treatment, women are in no condition to return to their professional routines, due to the physical limitations after surgery and the symptoms resulting from the treatments. ${ }^{22}$ It must be considered that this study had a sample in which the majority of patients in both groups were from a low class (82.2\%) and had an educational level of basic schooling (53.4\%), which could aggravate financial difficulties. CEPON, the place of data collection, is characterized as a public care center, with free access to patient, in which all are attended by the Brazilian national health system called Sistema Único de Saúde - SUS.23 This illustrates their difficult financial situation even further.

The relationship between PA and QOL was reported by the binary logistic regression analysis and obtained an important result with respect to the practice of walking. Each extra minute of walking per day, diminishes the probability of having low functional capacity by $1.9 \%$, and reduced probability of having an elevated symptomatology by 2.65 ; that is $19 \%$ and $26 \%$ respectively, per each additional block of 10 minutes of walking per day. In this study, walking was the PA most reported by the patients, with approximately 21 minutes per day. 
This fact, in healthy women is corroborated by the literature in population studies in Brazil, ${ }^{24}$ and specifically in Santa Catarina, ${ }_{1}^{25}$ where walking is also the most form of PA practiced.

This high rate of adhesion to walking, occurs because it is an activity that presents the lowest incidence of musculoskeletal lesions, ${ }^{26}$ and is considered pleasurable, with possibilities of practice in groups, is easily accessible, has low impact and low monetary cost. ${ }^{27}$ It has been seen as a simple health behavior that can bring significant benefits to the life of those who practice it. ${ }^{28}$ This form of PA is popular and inexpensive, and can be applied in women with $B C .{ }^{10,29}$ It can be an option for alleviating the adverse side effects of $B C$ treatment, improving the $\mathrm{QOL}$ and minimizing fatigue symptoms. ${ }^{29}$

The present study, showed that Brazilian women with BC did not achieve the amount of PA required. Which highlighted the need for more attention from the national public health institutes. In addition, the finding presents the possibility of walking as a type of physical activity that can enhance QOL. Considering that lack of Brazilian studies that investigate walking as a viable physical activity for $\mathrm{BC}$ women.

The present study had some limitations with reference to using the short version of the IPAQ questionnaire, considering that it is a subjective measure and has retrospective nature. Also, data related with the characteristics of the disease were self-reported, because the researchers had no access to the clinical record charts. In addition, as a cross-sectional study, it provided no cause and effect relations.

\section{CONCLUSIONS}

Post treatment women presented higher level of PA and better QOL. The period of clinical treatment must also receive attention, considering that the data pointed out this period as being critical about the practice of PA and QOL. The most important findings of this study go to the benefits obtained by means of increasing the practice of walking by 10 minutes per day for reducing symptomatology and low physical functioning of the QOL by $19 \%$ and $26 \%$ respectively. Because of this, health professionals should be alert to the need of encouraging the practice of walking and making it feasible to implement interventions that may ensure the PA for this population.

All authors declare no potential conflict of interest related to this article.

AUTHORS'CONTRIBUTIONS: Each author made significant individual contributions to this manuscript. LB (0000-0003-4978-9703)* and ACAG (0000-0001-5167-2921)*: contributed to the conception, design, data gathering, data analysis and interpretation, writing of the manuscript, and approval of the version submitted; AFB (0000-0001-6280-2525)*: contributed to the design, data analysis and interpretation, writing of the manuscript, and approval of the version submitted; GSP (0000-0001-6128-0649)*, MCSV (0000-0002-7861-7620* AAC $(0000-0002-0280-7567)^{*}$, TS $(0000-0002-4198-2923)^{*}$ and FB $(0000-0002-0214-5401)^{*}$ contributed to the data gathering, writing of the manuscript, and approval of the version submitted. *ORCID (Open Researcher and Contributor ID).

\section{REFERENCES}

1. Gavric Z, Vukovic-Kostic Z. Assessment of quality of life of women with breast cancer. Glob J Health Sci. 2016;8(9):1-9.

2. Brunet J, Amireault S, Chaiton $\mathrm{M}$, Sabiston CM. Identification and prediction of physical activity trajectories in women treated for breast cancer. Ann Epidemiol. 2014;24(11):837-42.

3. Zaidi S, Hussain S, Verma S, Vegar Z, Khan A, Nazir SU, et al. Efficacy of complementary therapies in the quality of life of breast cancer survivors. Front Oncol. 2017;7:326.

4. Schmidt ME, Wiskemann J, Ulrich CM, Schneeweiss A, Steindorf K. Self-reported physical activity behavior of breast cancer survivors during and after adjuvant therapy: 12 months follow-up of two randomized exercise intervention trials. Acta Oncol. 2017;56(4):618-27.

5. Tiezzi MF, De Andrade JM, Romão AP, Tiezzi DG, Lerri MR, Carrara HA, et al. Quality of life in women with breast cancer treated with or without chemotherapy. Cancer Nurs. 2017;40(2):108-16.

6. Johnsson A, Johnsson A, Johansson K. Physical activity during and after adjuvant chemotherapy in patients with breast cancer. Physiotherapy. 2013;99(3):221-7.

7. Li T, Wei S, Shi Y, Pang S, Qin Q, Yin J, et al. The dose-response effect of physical activity on cancer mortality: findings from 71 prospective cohort studies. Br J Sports Med. 2016;50(6):339-45.

8. Manneville F, Rotonda C, Conroy T, Bonnetain F, Guillemin F, Omorou AY. The impact of physical activity on fatigue and quality of life during and after adjuvant treatment for breast cancer. Cancer. 2018;124(4):797-806

9. Mason C, Alfano CM, Smith AW, Wang CY, Neuhouser ML, Duggan C, et al. Long-term physical activity trends in breast cancer survivors. Cancer Epidemiol Biomarkers Prev. 2013;22(6):1153-61.

10. Tsianakas V, Harris J, Ream E, Hemelrijck MV, Purushotham A, Mucci L, et al. CanWalk: a feasibility study with embedded randomised controlled trial pilot of a walking intervention for people with recurrent or metastatic cancer. BMJ Open. 2017;7:e013719.

11. WHO. World Health Organization. Global recommendations on physical activity for health, 18-64 years old. 2011. [acess in 2014 oct. 13]. Available at: http://www.who.int/dietphysicalactivity/physical-activityrecommendations-18-64years.pdf.

12. IBGE. Instituto Brasileiro de Geografia e Estatística. Projeção da população do Brasil/censo 2010. [acess in 2014 oct. 13]. Available at: http//www.ibge.gov.br.

13. Matsudo S, Araujo T, Matsudo V, Andrade D, Andrade E, Oliveira LC, et al. Questionário Internacional de Atividade Física (IPAQ): Estudo de Validade e Reprodutibilidade no Brasil. Rev Bras Ativ Fís Saúde. $2001 ; 6(2): 1-14$

14. Schmitz KH, Courneya KS, Matthews C, Demark-Wahnefried W, Galvao DA, Pinto BM, et al. American College of Sports Medicine roundtable on exercise guidelines for cancer survivors. Med Sci Sports Exerc. 2010;42(7):1409-26
15. Aaronson NK, Ahmedzai S, Bergman B, Bullinger M, Cull A, Duez NJ, et al. The European Organization for Research and Treatment of Cancer QLQ-C30: a quality-of-life instrument for use in international clinical trials in oncology. J Natl Cancer Inst. 1993;85(5):365-76.

16. Michels FA, Latorre MR, Maciel MS. Validity, reliability and understanding of the EORTC-C30 and EORTCBR23, quality of life questionnaires specific for breast cancer. Rev Bras Epidemiol. 2013;16(2):352-63.

17. Loh SY, Chew S, Lee S. Physical Activity and Women with Breast Cancer: Insights from Expert Patients. Asian Pac J Cancer Prev. 2011;12(1):87-94.

18. Fangel LMV, Panobianco MS, Kebbe LM, Almeida AM, Gozzo TO. Quality of life and daily activities performance after breast cancer treatment. Acta Paul Enferm. 2013;26(1):93-100.

19. Macedo GDN, Lucena NMG, Soares LMMM, Rocha POA, Gutiérre CV, López MCB. The Life Style Influence on the Quality of Life of Women with Breast Cancer. Rev Bras Ciênc Saúde. 2010;14(4):13-8.

20. Mansano-Schlosser TC, Ceolim MF. [Fatigue in the elderly undergoing chemotherapy]. Rev Bras Enferm. 2014;67(4):623-9.

21. Lamino DA, Mota DD, Pimenta CA. [Prevalence and comorbidity of pain and fatigue in women with breast cancer]. Rev Esc Enferm USP. 2011;45(2):508-14.

22. Vidor C, Leroyer A, Christophe V, Sillier M, Foncel J, Maele JV, et al. Decrease social inequalities return-to-work: development and design of a randomized controlled trial among women with breast cancer. BMC Cancer. 2014;23(1):214-67.

23. Schneider IJ, d'Orsi E. [Five-year survival and prognostic factors in women with breast cancer in Santa Catarina State, Brazil]. Cad Saude Publica. 2009;25(6):1285-96

24. Malta DC, Moura EC, Castro AM, Cruz DKA, Neto Morais OL, Monteiro CA. Physical Activities Pattern among Brazilian Adults: Results of Phone Survey, 2006. Epidemiol Serv Saúde. 2009;18(1):7-16.

25. Oliveira PA, Oliveira AG, Tillmann AC, Araujo CCR, Bertuol C, Pazin J, et al. Factors associated to usual physical activity in women. Rev Bras Med Esporte. 2015;21(2):99-103.

26. Saragiotto BT, Pripas F, Almeida MO, Yamato TP. Prevalence of musculoskeletal pain in walkers: a cross-sectional study. Fisioter Pesqui. 2015;22(1):29-33.

27. Rowe DA, Welk GJ, Heil DP, Mahar MT, Kemble CD, Calabró A, et al. Stride Rate Recommendations for Moderate-Intensity Walking. Med Sci Sports Exerc. 2011;43(2):312-8.

28. Lee IM, Buchner DM. The Importance of Walking to Public Health. Med Sci Sports Exerc. 2008:40(7 Suppl):S512-8

29. Baruth M, Wilcox S, Der Ananian C, Heiney S. Effects of Home-Based Walking on Quality of Life and Fatigue Outcomes in Early Stage Breast Cancer Survivors: A 12-Week Pilot Study. J Phys Act Health. 2015;12(Suppl 1):110-8. 